\title{
PEMODELAN DAN ESTIMASI KETIDAKPASTIAN PENGUKURAN UJI KEKUATAN SOBEK KAIN METODA PENDULUM (ELMENDORF)
}

\section{MODELING AND UNCERTAINTY ESTIMATION OF DETERMINATION TEAR FORCE USING BALLISTIC PENDULUM METHOD (ELMENDORF)}

\author{
Saeful Islam, M. Danny Sukardan \\ Balai Besar Tekstil, Jalan Jenderal Ahmad Yani No. 390 Bandung \\ E-mail: saeful.islm@gmail.com
}

Tanggal diterima: 19 Juli 2016, direvisi: 28 September 2016, disetujui terbit: 3 November 2016

\begin{abstract}
ABSTRAK
Sebuah penelitian tentang estimasi ketidakpastian pengukuran pada uji kekuatan sobek kain metoda pendulum (Elmendorf). Tujuan penelitian ini adalah untuk mendapatkan nilai dan parameter-parameter sumber ketidakpastian pengukuran pada uji kekuatan sobek kain metoda pendulum (Elmendorf). Dalam mengestimasi ketidakpastian pengukuran diperlukan model pengukuran yang merupakan fungsi yang menghubungkan besaran yang sedang diukur dengan besaran masukan. Pembuatan model pengukuran memerlukan pemahaman tentang proses utama dan hubungannya dengan besaran yang diukur. Proses utama uji sobek kain metoda pendulum (Elmendorf) yang berpengaruh pada besarnya gaya yang dibutuhkan untuk meneruskan sobekan adalah pemolaan dengan pola contoh uji (d), pemberian sobekan awal (s) hasil uji sobek kain (F) dan metoda uji (b). Dengan meneliti proses utama tersebut diperoleh formulasi perhitungan gaya sobek yang mengkaitkan faktor-faktor tersebut, yaitu: $\mathrm{FS}=\mathrm{F} \cdot \frac{\mathrm{b}}{(\mathrm{d}-\mathrm{s})}$. Mengacu pada formulasi tersebut maka komponen-komponen ketidakpastian pengukuran dapat diidentifikasi, yaitu: repeatability hasil uji, penunjukan gaya pada alat uji sobek (Elmendorf), panjang contoh uji, panjang sobekan yang diteruskan, panjang sobekan awal dan konstanta ketetapan ukuran pada metode uji (SNI ISO 13937-1:2010). Dari keenam komponen tersebut yang memberikan kontribusi yang cukup besar pada ketidakpastian pengukuran yang dihasilkan adalah ketidakpastian repetability hasil pengujian, ketidakpastian panjang sobekan yang diteruskan dan ketidakpastian konstanta. Dengan diketahuinya faktorfaktor ketidakpastian, maka ketidakpastian pengukuran uji kekuatan sobek kain metoda pendulum (Elmendorf) dapat diestimasi.
\end{abstract}

Kata kunci: ketidakpastian pengukuran, gaya sobek, Elmendorf

\section{ABSTRACT}

A research on the estimation of measurement uncertainty at test fabric tear strength pendulum method (Elmendorf). The purpose of this study is to get a value, and a source of uncertainty parameters measurements on test fabric tear strength pendulum method (Elmendorf). In measurement uncertainty estimating is required measurement model which is a function that relates the measurand and input parameter quantities. Measurement modeling requires an understanding of the mainprocess and its relationship with the measurand. The main process of determination tear force using ballistic pendulum (Elmendorf), which affects the amount of required tear force were the patterning of the pattern of the specimen $(d)$, the provision ofinitialtear $(s)$ test tear results $(F)$ andtestmethod $(b)$. By examining the main process obtained the formulations of tear force calculations that related to these factors, was $\mathrm{FS}=\mathrm{F} \cdot \frac{\mathrm{b}}{(\mathrm{d}-\mathrm{s})}$. Referring to the formulation of the measurement uncertainty factors can be identified, that were uncertainty of test result repeatability, uncertainty of tear test apparatus, uncertainty of the length of sample, uncertainty of the length of initial tear, uncertainty of the tear length continued, and uncertainty of constants determination of test method (SNI ISO 13937-1:2010). From the six components that provide a substantial contribution to the measurement uncertainty is the uncertainty generated repetability test result the uncertainty of long tear which continued and constant uncertainty. By knowing the factors of uncertainty, the uncertainty of measurement of fabric tear strength test pendulum method (Elmendorf) can be estimated.

Keyword : measurement uncertainty, tear force, Elmendorf 


\section{PENDAHULUAN}

Penilaian kesesuaian suatu produk seringkali mencakup nilai terukur yang terletak dalam rentang ketidakpastian. Kurangnya dalam pemahaman terhadap ketidakpastian pengukuran ini dapat mengakibatkan penolakan suatu komoditi karena perbedaan hasil penilaian. Dalam era pasar global diperlukan metode untuk mengevaluasi dan menyatakan ketidakpastian yang dapat diterima di seluruh dunia sehingga pengukuran yang dilakukan dapat dibandingkan dengan mudah ${ }^{1}$. Hasil pengukuran adalah lengkap hanya jika disertai dengan pernyataan kuantitatif ketidakpastiannya. ${ }^{2}$ Ketidakpastian adalah parameter hasil pengukuran yang memberikan karakter sebaran nilai-nilai yang secara layak dapat diberikan pada besaran ukur. ${ }^{3}$

Adanya estimasi ketidakpastian pengukuran memungkinkan dilakukannya perbandingan hasil antar laboratorium yang berbeda atau dalam laboratorium yang sama, atau perbandingan hasil dengan nilai acuan yang diberikan dalam spesifikasi atau standar. Perbedaan nilai hasil uji suatu produk mungkin saja tidak signifikan jika perbedaan tersebut masih dalam rentang ketidakpastian. Estimasi seluruh komponenyang berkontribusi terhadap ketidakpastian hasil pengukuran atau pengujian menjadikan pengukuran yang dilakukan dan hasil yang diperoleh valid. ${ }^{4}$ Ketidakpastian pengukuran juga menunjukkan akurasi yang dihasilkan oleh suatu laboratorium uji dan memberikan informasi lengkap tentang hasil analisis. Hal ini sangat penting karena beberapa keputusan tentang kesesuaian suatu produk dengan spesifikasi atau standard yang ditetapkan, seperti dalam bidang farmasi ${ }^{5,6,7}$, kelistrikan ${ }^{8,9}$ dan lingkungan.

SNI ISO/IEC 17025, menyajikan suatu persyaratan umum untuk kompetensi laboratorium pengujian dan laboratorium kalibrasi, dijadikan acuan oleh Komite Akreditasi Nasional (KAN) dalam melakukan akreditasi laboratorium pengujian.Dalam standar ini laboratorium pengujian harus mempunyai dan menerapkan prosedur untuk mengestimasi ketidakpastian pengukuran. ${ }^{\mathbf{1 0}}$

Sifat mekanis kain yang menentukan peruntukan kain yang paling banyak dipersyaratkan adalah kekuatan tarik, kekuatan sobek dan sifat elastisitas ${ }^{11}$. Kekuatan sobek adalah faktor yang sangat pentinguntuk kain yang digunakan untuk sandang dan menjadi persyaratan mutu untuk kain tersebut bahkan disebutkan secara jelas tentang penentuan kekuatan sobek menggunakan metoda pendulum (Elmendorf), seperti pada kain tenun untuk kemeja, kain tenun untuk setelan, dan kain georgette. . $^{13,14}$

Uji kekuatan sobek kain metoda pendulum (Elmendorf) merupakan salah satu item uji yang ada di Laboratorium Pengujian Balai Besar Tekstil yang sudah terakreditasi oleh KAN. Uji ini mengacu pada SNI ISO 13937-1:2010. Laboratorium Balai Besar Tekstil belum menerapkan perhitungan ketidakpastian terutama pada uji kekuatan sobek kain. Kajian ini dibuat untuk mengestimasi ketidakpastian pengukuran uji kekuatan sobek kain menggunakan metoda pendulum (Elmendorf).

\section{METODE}

Saat mengestimasi ketidakpastian pengukuran, semua komponen ketidakpastian yang penting dalam situasi yang ada harus diperhitungkan dengan menggunakan metoda analisis yang sesuai. ${ }^{5}$ Metoda yang digunakan untuk mengestimasi ketidakpastian pengukuran uji kekuatan sobek kain ini menggunakan KAN-G-01 (2011): KAN Guide on The Evaluation and Expression of Uncertainty in Measurement. Diagram alir estimasi ketidakpastian pengukuran uji kekuatan sobek kain metoda pendulum (Elmendorf) dapat dilihat pada Gambar 1.

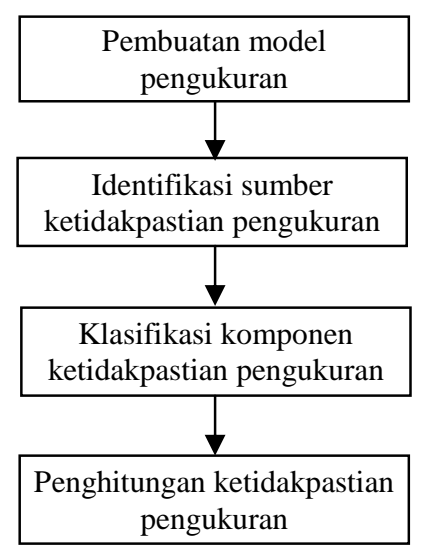

Gambar 1.Diagram alir estimasi ketidakpastian pengukuran uji kekuatan sobek kain metoda pendulum (Elmendorf)

Model pengukuran adalah suatu fungsi yang menghubungkan besaran yang diukur dengan besaran masukan. Dalam sebagian besar proses pengukuran, besaran ukur $\mathrm{Y}$ ditentukan dari $\mathrm{N}$ besaran lain yaitu $X_{1}, X_{2}, \ldots X_{N}$ melalui hubungan fungsional seperti pada persamaan (1).

$$
Y=f\left(X_{1}, X_{2}, \ldots . X_{N}\right) \ldots \ldots . .(1)
$$

Model pengukuran memerlukan pernyataan yang jelas tentang besaran yang diukur, dan pernyataan kuantitatif yang menunjukkan hubungan antara nilai besaran ukur dan variabel bebas dimana besaran ukur tersebut bergantung. Parameter tersebut dapat berupa besaran ukur lain, besaran yang tidak langsung diukur, atau suatu konstanta.

Dari model pengukuran, kemudian diidentifikasi sumber-sumber ketidakpastian yang berkaitan dengan proses pengukuran. Untuk membantu proses identifikasi sumber 
ketidakpastian pengukuran, terutama untuk proses pengukuran yang melibatkan banyak besaran maupun besaran yang berpengaruh dapat menggunakan diagram sebab akibat model tulang ikan (fish bone).

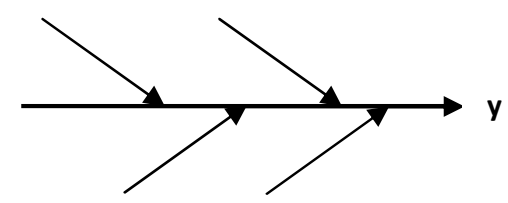

Gambar 2. Diagram tulang ikan

Ketidakpastian pengukuran terdiri dari beberapa komponen yang dapat diklasifikasikan menurut metode yang digunakan untuk menaksir nilai numeriknya ${ }^{1}$, yaitu :

- Tipe A : yang dievaluasi dengan analisis dari serangkaian pengamatan.

- Tipe B : yang dievaluasi dengan cara selain analisis statistik dari serangkaian pengamatan.

Ketidakpastian pengukuran setiap besaran input, dihitung dan digabungkan menjadi ketidakpastian baku gabungan. Dalam menggabungkan ketidakpastian, koefisien sensitifitas (c) harus diperhitungkan untuk menyamakan satuan dan memberikan bobot pada setiap komponen ketidakpastian. Koefisien sensitifitas dihitung berdasarkan turunan parsial dari fungsi yang mewakili model matematis pengukurannya, seperti ditunjukkan pada persamaan (2).

$$
\mathrm{c}=\frac{\partial \mathrm{f}}{\partial \mathrm{x}} \ldots \ldots(2)
$$

\section{HASIL DAN PEMBAHASAN}

\section{Penyusunan Model Pengukuran}

\section{a. Pembuatan Model Pengukuran}

Untuk dapat membuat model pengukuran uji sobek kain metoda pendulum (Elmendorf), diperlukan definisi prosedur uji sobek kain dan gaya sobek metoda pendulum (Elmendorf).

Proses utama pengujian uji sobek kain metoda pendulum (Elmendorf), seperti yang dapat dilihat pada Gambar 3. Contoh uji dikondisikan, kemudian proses pemolaan dan pemotongan contoh uji pada proses pemotongan contoh uji biasanya menggunakan pola contoh dengan ukuran tertentu sesuai dengan SNI ISO 13937-1 seperti pada Gambar 13. Kemudian contoh uji ditempatkan di diantara dua pasang penjepit dengan sisi bawah contoh uji dijepit pada bagian bawah penjepit yang ada pada alat uji. Dengan pisau yang ada pada alat uji, sobekan awal pada kain dibuat. Skema gambar alat uji sobek kain metoda pendulum (Elmendorf) dapat dilihat pada Gambar 4.
Gaya sobek didefinisikan sebagai gaya yang diperlukan untuk meneruskan sobekan pada kain ditentukan dengan mengukur kerja yang dilakukan dalam penyobekan kain dengan jarak yang ditentukan ${ }^{15}$. Dari definisi tersebut dapat dipahami bahwa gaya sobek (FS) berbanding lurus dengan gaya yang dihasilkan oleh alat uji sobek (F) untuk meneruskan sobekan awal dan konstanta panjang sobekan yang ada pada SNI ISO 13937-1 (b). Dari definisi tersebut dapat dibuat formulasi matematikaseperti ditunjukkan pada persamaan (3).

$$
\mathrm{FS}=\mathrm{F} \cdot \mathrm{b}
$$

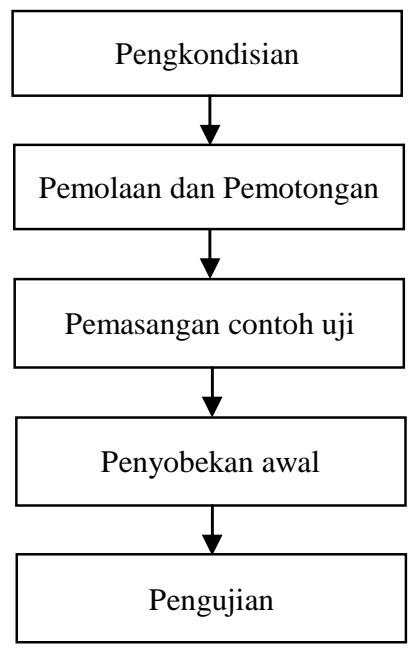

Gambar 3. Diagram alir pengujian kekuatan sobek kain metoda pendulum (Elmendorf)

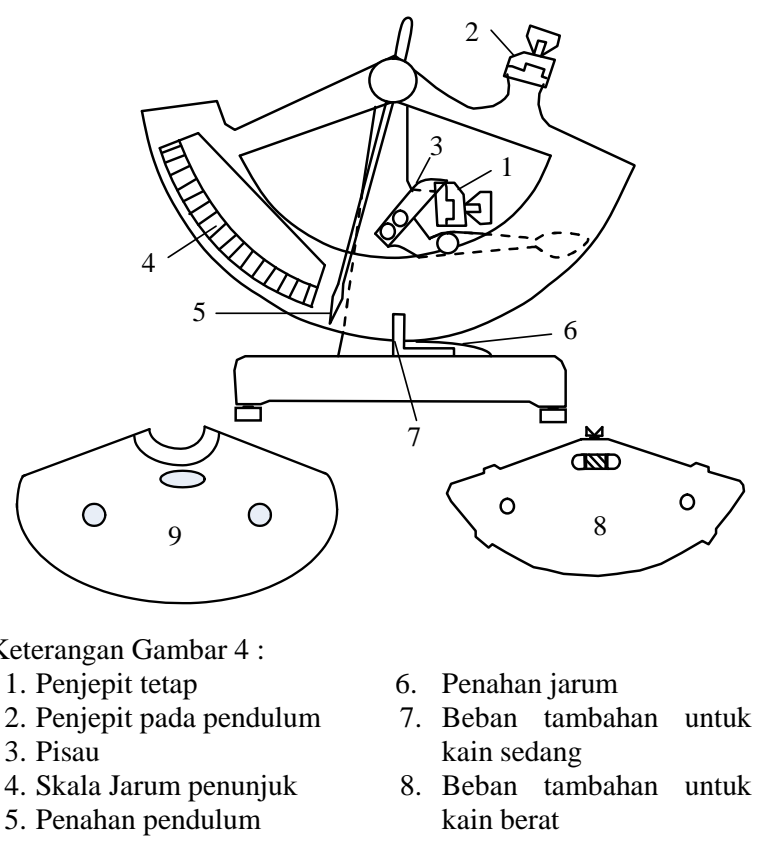

Gambar 4. Alat uji sobek kain metoda pendulum (Elmendorf) 
Apabila panjang sobekan kain yang diteruskan (a) sama dengan konstanta panjang sobekan yang ada pada SNI ISO 13937-1 (b) maka gaya sobek (FS) sama dengan gaya yang ditunjukkan oleh alat Elmendorf (F). Apabila panjang sobekan kain yang diteruskan (a) lebih kecil dari konstanta panjang sobekan (b) maka gaya yang ditunjukkan oleh alat Elmendorf (F) lebih kecil dari yang seharusnya, gaya sobek yang sebenarnya (FS) harus lebih besar dari gaya yang ditunjukkan oleh alat Elmendorf. Begitu juga apabila sobekan kain yang diteruskan (a) lebih besar dari konstanta panjang sobekan (b) maka gaya yang ditunjukkan oleh alat Elmendorf (F) lebih besar dari yang seharusnya, gaya sobek yang sebenarnya harus lebih kecil dari gaya yang ditunjukkan oleh Elmendorf (F). Dengan kata lain gaya sobek (FS) berbanding terbalik dengan panjang sobekan yang diteruskkan (a). Sehingga persamaan (3) dapat dibuat menjadi :

$$
\mathrm{FS}=\mathrm{F} \cdot \frac{\mathrm{b}}{\mathrm{a}} \ldots \ldots \ldots
$$

Panjang sobekan yang diteruskan (a) merupakan selisih dari panjang contoh uji (d) dan panjang sobekan awal (s), untuk lebih jelasnya dapat melihat pada Gambar 5, atau dengan formulasi matematika,sebagai berikut :

$$
a=(d-s)
$$

Pada persaman (4), variabel (a) disubtitusi dengan persamaan (5), sehingga persamaan (4) menjadi:

$$
\mathrm{FS}=\mathrm{F} \cdot \frac{\mathrm{b}}{(\mathrm{d}-\mathrm{s})} \ldots \ldots(6)
$$

Dengan: $F S=$ gaya sobek, gf atau N

$$
\begin{array}{ll}
\mathrm{F} & \text { : penunjukan alat (Elmendorf), gf atauN } \\
\mathrm{b} & \text { : konstanta panjang sobekan yang } \\
& \text { diteruskan, } 43 \mathrm{~mm} \\
\mathrm{~d} & \text { : panjang contoh uji (pola contoh uji), } \mathrm{mm} \\
\mathrm{s} & \text { : panjang sobekan awal, mm } \\
\mathrm{a} & \text { : panjang kain yang sobekannya akan } \\
& \text { diteruskan, mm }
\end{array}
$$

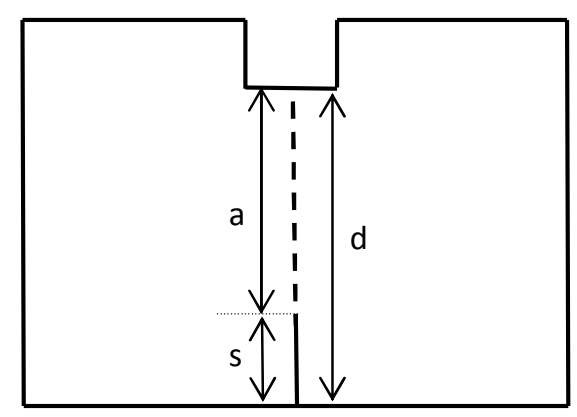

Gambar 5. Pola contoh uji
Dari persamaan (6) terlihat bahwa gaya sobek yang dihasilkan tidak hanya dipengaruhi oleh penunjukan hasil uji alat Elmendorf, tetapi juga dipengaruhi oleh panjang contoh uji yang dihasilkan oleh konstanta panjang sobekan yang diteruskan, pola contoh uji, dan panjang sobekan awal.

\section{b. Identifikasi Sumber Ketidakpastian \\ Pengukuran}

Berbagai faktor untuk menentukan kebenaran dan kehandalan pengujian yang dilakukan oleh laboratorium, meliputi: faktor manusia, kondisi akomodasi dan lingkungan, metode pengujian, peralatan, ketertelusuran pengukuran, pengambilan contoh dan penanganan barang yang diuji. Kontribusi masing-masing faktor terhadap ketidakpastian pengukuran total sangat berbeda pada (tipe) pengujian yang satu dan yang lainnya. ${ }^{10}$

Faktor yang mempengaruhi ketidakpastian pengukuran untuk uji sobek kain cara pendulum (Elmendorf) adalah peralatan dan metoda, seperti yang ditunjukkan Gambar 6. Faktor manusia tidak diperhitungkan karena dalam SNI ISO/IEC 17025 pengujian harus dilakukan oleh orang yang kompeten dengan menggunakan metoda yang diakui secara nasional dan internasional, sehingga kesalahan karena faktor manusia diabaikan.Begitu pula dengan kondisi lingkungan, dalam SNI ISO/IEC 17025 disebutkan bahwa laboratorium harus memastikan kondisi lingkungan tidak mengakibatkan ketidakabsahan hasilatau berpengaruh buruk pada mutu setiap pengukuran yang dipersyaratkan.

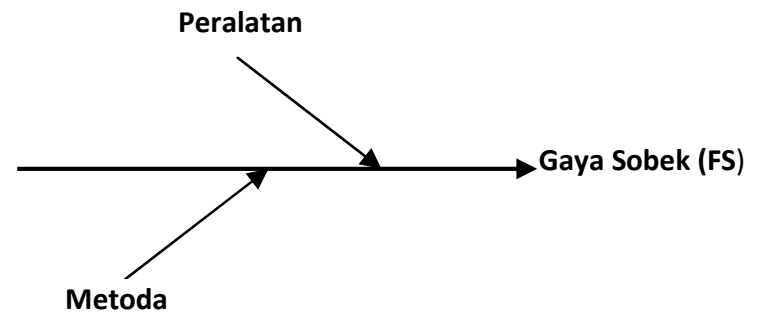

Gambar 6. Cabang utama sumber ketidakpastian uji sobek kain metoda pendulum (Elmendorf).

Dari cabang utama pada Gambar 6, selanjutnya dibuat cabang yang menjadi sumber ketidakpastian pengukuran. Persamaan (6) dijadikan sebagai acuan untuk mengidentifikasi sumber-sumber ketidakpastian tersebut. Pada cabang utama peralatan dapat dirinci menjadi tiga sumber ketidakpastian, yaitu: hasil uji, pola contoh uji dan sobekan awal. Sedangkan untuk metoda dipengaruhi oleh ketentuan pola contoh uji yang ada pada SNI ISO 13937-1 (2010) sebagai standar akan memberikan ketidakpastian pada konstanta 
(b). Untuk lebih jelasnya dapat dilihat pada Gambar 7.

\section{c. Klasifikasi Komponen Ketidakpastian Pengukuran \\ Repeatability hasil uji termasuk komponen} ketidakpastian tipe A karena merupakan hasil dari serangkaian pengamatan/pengukuran. Untuk masing-masing jenis contoh uji dilakukan uji kekuatan sobek kain sebanyak n kali pengukuran; minimal 5 contoh uji. ${ }^{15}$ Hasilnya dirata-ratakan dan dihitung simpangan bakunya. Simpangan baku menggambarkan sebaran nilai yang dapat digunakan mewakili seluruh populasi nilai terukur. Sedangkan yang lainnya yaitu sumber ketidakpastian dari alat uji, pola contoh uji, panjang sobekan awal, dan konstanta yang berasal dari SNI ISO 13937-1 merupakan komponen ketidakpastian tipe B.

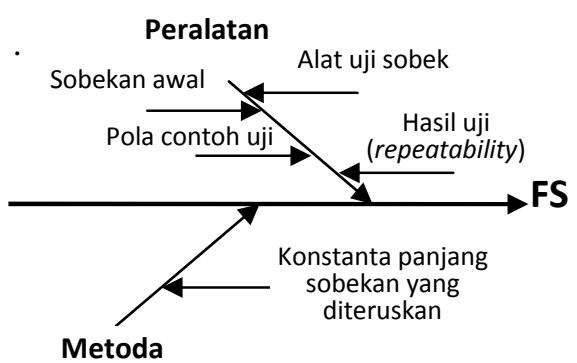

Gambar 7. Sumber ketidakpastian uji sobek kain metoda pendulum (Elmendorf).

Ketidakpastian alat uji dan pola contoh uji, memberikan ketidakpastian pengukuran yang dapat dilihat dari sertifikat kalibrasinya. Sedangkan ketidakpastian konstanta panjang sobekan yang diteruskan dianalisa berdasarkan ketentuan ukuran contoh uji yang ada pada SNI ISO 13937-1.

Ketika ketidakpastian pengukuran diberikan dalam batas tertentu \pm a, distribusi kemungkinan dapat diestimasi dari informasi yang tersedia, yang kemungkinan dapat berbentuk berbagai distribusi ${ }^{1}$ sebagai berikut:

\section{- Distribusi rectangular}

Digunakan bila batas dapat ditentukan namun nilai besaran ukur tampak berada di semua tempat dalam ruang tersebut. Ketidakpastian baku diperoleh dengan membagi semi-range ' $a$ ' dengan $\sqrt{3}$, yaitu $u= \pm \frac{a}{\sqrt{3}}$, seperti terlihat pada Gambar 8 .

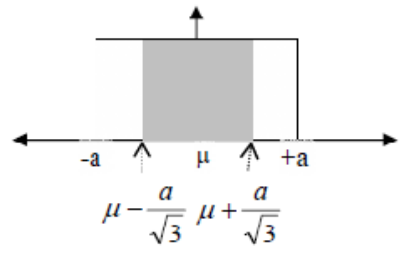

Gambar 8. Distribusi rectangular

\section{- Distribusi triangular}

Digunakan bila terdapat bukti bahwa nilai yang paling mungkin adalah nilai yang dekat dengan nilai rata-rata. Ketidakpastian baku diperoleh dengan membagi semi-range 'a' dengan $\sqrt{6}$, yaitu $u= \pm \frac{a}{\sqrt{6}}$, seperti terlihat pada Gambar 9 .

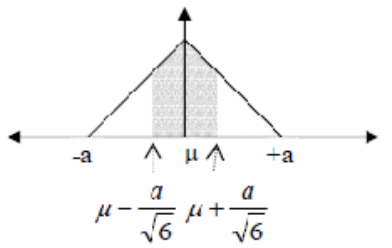

Gambar 9. Distribusi triangular

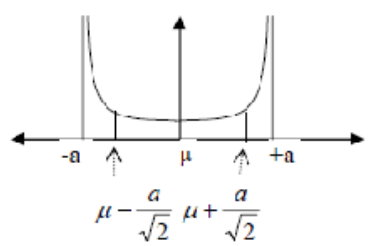

Gambar 10. Distribusi bentuk U

\section{- Distribusi Normal}

Digunakan bila diasumsikan untuk ketidakpastian pengukuran yang menyatakan tingkat kepercayaan tertentu. Ketidakpastian baku diperoleh dengan membagi ketidakpastian tersebut dengan faktor cakupan yang tepat berdasarkan tabel distribusi-t, yaitu $u= \pm \frac{U}{k}$; dimana $U$ adalah ketidakpastian bentangan dengan tingkat kepercayaan tertentu dan $\mathrm{k}$ adalah faktor cakupan.

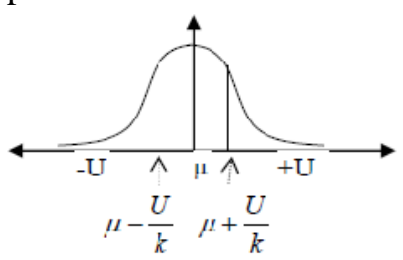

Gambar11. Distribusi normal

\section{d. Perhitungan ketidakpastian pengukuran}

Perhitungan ketidakpastian pengukuran uji kekuatan sobek kain menggunakan metoda pendulum (Elmendorf), yaitu :

1. Repetability hasil uji Elmendorf

Ketidakpastian repeatability hasil pengujian dihitung berdasarkan simpangan baku rata-rata. Bila dilakukan $\mathrm{n}$ kali pengukuran maka ${ }^{1}$ :

$$
\begin{aligned}
& \bar{x}=\frac{1}{n} \sum_{1}^{n} x_{i} \ldots \ldots \ldots \ldots \ldots(7) \ldots \ldots \\
& s\left(x_{i}\right)=\sqrt{\frac{\sum_{i=1}^{n}\left(x_{i}-\bar{x}\right)^{2}}{n-1}} \ldots \ldots \ldots(8)
\end{aligned}
$$




$$
s(\bar{x})=\frac{s\left(x_{i}\right)}{\sqrt{n}}
$$

Dengan:

$\mathrm{n} \quad=$ jumlah pengukuran

$\bar{x}=$ rata-rata hasil pengukuran

$s\left(x_{i}\right)=$ simpangan baku

$s(\bar{x}) \quad=$ simpangan baku rata-rata

Ketidakpastian pengukuran dari repeatability adalah simpangan baku rata-rata eksperimental, yaitu :

$$
u_{1}= \pm s(\bar{x}) \ldots \ldots(10)
$$

Ketidakpastian repeatability diambil dari hasil pengukuran Elmendorf, sehingga koefisien sensitifitasnya sebagai berikut :

$$
\begin{array}{r}
c_{1}=\frac{\partial F S}{\partial F} \\
c_{1}=\frac{b}{(d-s)} \ldots
\end{array}
$$

2. Penunjukan gaya pada alat uji sobek

Alat uji yang digunakan untuk menyobek kain akan memberikan ketidakpastian. Ketidakpastian alat uji ini dapat dilihat dari sertifikat kalibrasi dari alat uji tersebut dan mempunyai distribusi normal. Persamaan ketidakpastiannya adalah sebagai berikut :

$$
\mathrm{u}_{2}= \pm \frac{\mathrm{U}_{95 \% \mathrm{~F}}}{\mathrm{k}_{\mathrm{F}}}
$$

\section{Dengan}

$\mathrm{U}_{95 \% \mathrm{~F}}=$ ketidakpastian penunjukan gaya pada alat uji sobek (Elmendorf), gf atau N

$\mathrm{k}_{\mathrm{F}} \quad=$ faktor cakupan

Faktor cakupan adalah faktor numerik yang digunakan sebagai pengali terhadap ketidakpastian baku gabungan untuk memperoleh ketidakpastian bentangan.

Ketidakpastian penunjukkan gaya pada alat uji sobek (Elmendorf) diperoleh dari sertifikat kalibrasi alat uji sobek Elmendorf, sehingga koefisien sensitifitasnya $\left(c_{2}\right)$ adalah sebagai berikut :

$$
\begin{gathered}
\mathrm{c}_{2}=\frac{\partial \mathrm{FS}}{\partial \mathrm{F}} \\
\mathrm{c}_{2}=\frac{\mathrm{b}}{(d-s)} \ldots \ldots
\end{gathered}
$$

3. Panjang contoh uji

Pola contoh uji biasanya digunakan untuk memudahkan dalam hal pembuatan pola dan pengguntingan sampel. Pola contoh uji ini menentukan panjang contoh uji (d) yang akan disobek dan akan mempengaruhi kekuatan sobek kain, seperti pada Gambar 5. Ketidakpastian pengukuran panjang contoh uji yang akan disobek dapat dilihat pada sertifikat kalibrasi dari pola contoh uji. Ketidakpastian ini mempunyai distribusi normal sehingga persamaan ketidakpastian adalah:

$$
\mathrm{u}_{3}= \pm \frac{\mathrm{U}_{95 \% \mathrm{~d}}}{\mathrm{k}_{\mathrm{d}}} \ldots \ldots
$$

$$
\begin{aligned}
& \text { Dengan } \\
& \begin{aligned}
\mathrm{L}_{95 \% \mathrm{~d}}= & \text { ketidakpastian panjang contoh uji } \\
& \text { yang akan disobek, } \mathrm{mm}
\end{aligned} \\
& \mathrm{k} \quad=\text { faktor cakupan }
\end{aligned}
$$

Ketidakpastian panjang contoh uji yang akan disobek mempunyai satuan panjang ( $\mathrm{mm})$, sedangkan satuan gaya adalah gf atau $\mathrm{N}$. Sehingga diperlukan koefisien sensitifitas untuk menyamakan satuan dan memberikan bobot. Evaluasi koefisien sensitifitasnya dapat dilakukan bedasarkan turunan pertama dari fungsi yang mewakili model matematis pengukuran, yaitu sebagai berikut :

$$
\begin{gathered}
\mathrm{c}_{3}=\frac{\partial \mathrm{FS}}{\partial \mathrm{d}} \\
\mathrm{c}_{3}=\mathrm{F} \cdot \frac{\mathrm{b}}{(d-s)^{2}} \ldots \ldots \ldots \ldots . . . \\
\mathrm{c}_{3}=\frac{43 \mathrm{~F}}{(d-s)^{2}} \mathrm{gf} / \mathrm{mm} \ldots .(16)
\end{gathered}
$$

4. Panjang sobekan yang diteruskan

Panjang sobekan akan diteruskan $(\mathrm{d}-\mathrm{s})$, mempengaruhi gaya yang dibutuhkan untuk meneruskan sobekan pada kain tersebut. Pengujian dianggap benar jika sobekannya sempurna dan sampai daerah celah sobekan 15 $\mathrm{mm}^{11}$.

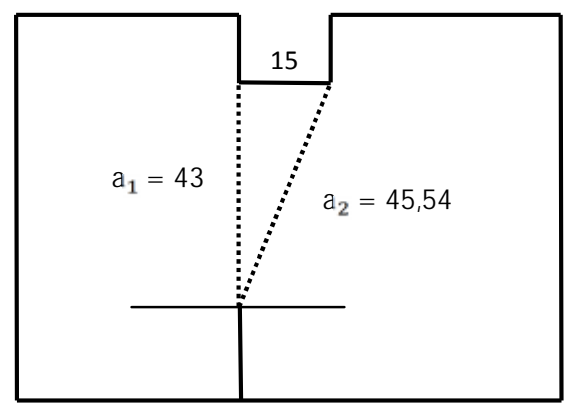

Gambar 12. Panjang sobekan yang diteruskan (mm)

Pada Gambar 12, terlihat bahwa panjang sobekan yang diteruskan dari hasil uji kemungkinan terpendek adalah $\mathrm{a}_{1}=43 \mathrm{~mm}$ dan 
Pemodelan dan Estimasi Ketidakpastian Pengukuran Uji Kekuatan Sobek Kain Metoda Pendulum (Elmendorf) (Saeful Islam, M. Danny Sukardan)

yang terjauh adalah $\mathrm{a}_{2}=45,54 \mathrm{~mm}$. Nilai $\mathrm{c}$ diperoleh dari rumus phytagoras $a_{2}=$ $\sqrt{a_{1}^{2}+\overline{15}^{2}}$. Panjang sobekan yang diteruskan dari hasil pengujian berada pada antara $43 \mathrm{~mm}$ sampai 45,54 mm, sehingga ketidakpastian pengukuran panjang sobekan kain adalah setengah selisih panjang sobek terpanjang dengan panjang sobek terkecil. Distribusinya adalah distribusi rectangular karena tidak diperhitungkan panjang sobekan yang ada, asalkan masih dalam celah $15 \mathrm{~mm}$. Sehingga ketidakpastian pengukurannya adalah sebagai berikut :

$$
\begin{array}{r}
\mathrm{u}_{4}= \pm \frac{1}{2} \frac{\left(\mathrm{a}_{2}-\mathrm{a}_{1}\right)}{\sqrt{3}} \ldots \ldots \ldots \ldots \ldots \ldots \ldots \\
u_{4}= \pm \frac{1}{2} \cdot \frac{(45,54-43)}{\sqrt{3}} \\
u_{4}= \pm 0,73323 \mathrm{~mm} \ldots \ldots
\end{array}
$$

Sedangkan kofisien sensitifitasnya adalah sebagai berikut :

$$
\begin{gathered}
\mathrm{c}_{4}=\frac{\partial \mathrm{FS}}{\partial(\mathrm{d}-\mathrm{s})} \\
\mathrm{c}_{4}=-\mathrm{F} \cdot \frac{\mathrm{b}}{(d-s)^{2}} \ldots \ldots \ldots \ldots . . . \\
\mathrm{c}_{4}=-\frac{43 \mathrm{~F}}{(d-s)^{2}} \mathrm{gf} / \mathrm{mm} \ldots
\end{gathered}
$$

5. Panjang sobekan awal

Panjang sobekan awal (s) diperhitungkan dalam perhitungan ketidakpastian pengukuran, karena panjang sobekan awal akan mempengaruhi panjang sobekan yang diteruskan dan gaya yang dibutuhkan untuk meneruskan sobekan. Ketidakpastian panjang sobekan awal dapat dilihat pada sertifikat kalibrasi alat ujinya. Distribusinya adalah distribusi normal sehingga ketidakpastian bakunya adalah sebagai berikut :

$$
\mathrm{u}_{5}= \pm \frac{\mathrm{U}_{95 \%} \mathrm{~s}}{\mathrm{k}_{\mathrm{s}}}
$$

\section{Dengan}

$\mathrm{L}_{95 \%} \mathrm{~s}=$ panjang sobekan awal, $\mathrm{mm}$

$\mathrm{k}=$ faktor cakupan

Sedangkan kofisien sensitifitasnya adalah sebagai berikut :

$$
\begin{array}{r}
c_{5}=\frac{\partial F S}{\partial s} \\
c_{5}=-F \cdot \frac{b}{(d-s)^{2}} \ldots \ldots . .
\end{array}
$$

$$
\mathrm{c}_{5}=-\frac{43 \mathrm{~F}}{(d-s)^{2}} \mathrm{gf} / \mathrm{mm}
$$

\section{Konstanta}

Konstanta atau ketetapanpanjang kain yang akan diteruskan sobekannya yang ada pada SNI ISO 13937-1, adalah seperti pada Gambar 13.

Pada Gambar 13, konstanta (b) atau panjang kain yang akan diteruskan sobekannya pada SNI ISO 13937-1 mempunyai beberapa persamaan sebagai berikut :

$$
\begin{aligned}
& b_{1}=43 \pm 0,5 \\
& b_{2}=(63 \pm 1)-(20 \pm 0,5) \\
& b_{2}=43 \pm 1,5 \\
& b_{3}=(75 \pm 2)-(20 \pm 0,5)-(12 \pm 0,5) \\
& b_{3}=43 \pm 3
\end{aligned}
$$

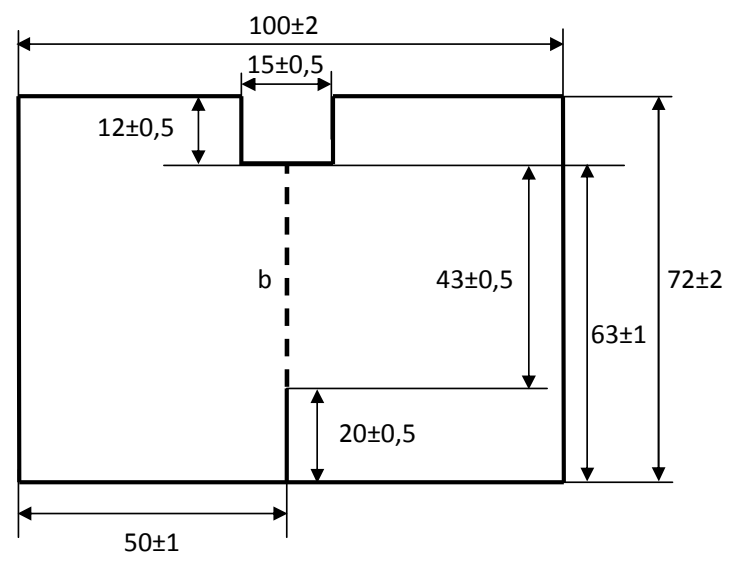

Gambar 13. Ukuran contoh uji (mm $)^{9}$

Ketiga persamaan konstanta tersebut mempunyai ketidakpastian yang berbeda. Ketidakpastian pengukuran untuk konstanta ini diambil dari ketidakpastian konstanta terbesar yaitu konstanta $b_{3}$ atau persamaan (24). Ketidakpastian konstanta yang berasal dari standar ini mempunyai distribusi rectangular karena tidak terdapat informasi apapun terkait sebarannya, sehingga ketidakpastian untuk konstanta ini adalah sebagai berikut :

$$
\begin{aligned}
& \mathrm{u}_{6}= \pm \frac{1}{2} \cdot \frac{3}{\sqrt{3}} \ldots \ldots \ldots \ldots \\
& \mathrm{u}_{6}= \pm 0,86603 \mathrm{~mm}
\end{aligned}
$$

Sedangkan kofisien sensitifitasnya untuk konstanta ini adalah sebagai berikut :

$$
c_{6}=\frac{\partial F S}{\partial b}
$$




$$
c_{6}=\frac{F}{(d-s)} \ldots \ldots
$$

7. Ketidakpastian baku gabungan

Ketidakpastian baku gabungan adalah gabungan ketidakpastian masing-masing unsur yang memberikan kontribusi pada ketidakpastian pengukuran. Ketidakpastian baku gabungan, nilainya sama dengan akar kuadrat positif dari jumlah semua suku yang merupakan varian atau kovarian bersama yang lain tersebut yang telah diberi bobot sesuai dengan bagaimana hasil perhitungan bervariasi terhadap perubahan bersama tersebut, ${ }^{1}$ secara matematis sebagai berikut :

$$
u_{c}=\sqrt{\sum_{i=1}^{N}\left(u_{i} \cdot c_{i}\right)^{2}}
$$

8. Ketidakpastian bentangan

Ketidakpastian bentangan merupakan ukuran ketidakpastian yang mendefinisikan interval hasil pengukuran di mananilai ukur tersebut diyakini berada. ${ }^{2}$ Ketidakpastian bentangan diperoleh dengan mengalikan ketidakpastian baku gabungan $\left(u_{c}\right)$ dengan faktor cakupan $(\mathrm{k})$. Untuk tekstil faktor cakupan yang digunakan adalah 2 dengan tingkat kepercayaan $95 \%$.

$$
\begin{aligned}
& \mathrm{U}=\mathrm{k} \cdot \mathrm{u}_{\mathrm{c}} \ldots \ldots .(30) \\
& \mathrm{U}_{95 \%}=2 \mathrm{u}_{\mathrm{c}} \ldots \ldots(31)
\end{aligned}
$$

Berdasarkan hal tersebut di atas, estimasi ketidakpastian uji kekuatan sobek kain metoda

\begin{tabular}{|c|c|c|c|c|c|c|}
\hline Komponen Ketidakpastian & Satuan & Distribusi & $\mathbf{u}_{\mathbf{i}}$ & $c_{i}$ & $\mathbf{u}_{\mathrm{i}} \cdot \mathbf{c}_{\mathrm{i}}$ & $\left(u_{i} \cdot c_{i}\right)^{2}$ \\
\hline Repeatability hasil pengujian & gf & & $\mathrm{s}(\overline{\mathrm{x}})$ & $\frac{\mathrm{b}}{(d-s)}$ & $\mathrm{s}(\overline{\mathrm{x}}) \cdot \frac{\mathrm{b}}{(d-\bar{s})}$ & $\left|\mathrm{s}(\overline{\mathrm{x}}) \cdot \frac{\mathrm{b}}{(d-s)}\right|^{2}$ \\
\hline Penunjukkan gaya pada alat uji sobek & gf & normal & $\frac{\mathrm{U}_{95 \% \mathrm{~F}}}{\mathrm{k}_{\mathrm{F}}}$ & $\frac{\mathrm{b}}{(d-s)}$ & $\frac{\mathrm{U}_{95 \%} \mathrm{~F}}{\mathrm{k}_{\mathrm{F}}} \cdot \frac{\mathrm{b}}{(d-s)}$ & $\left|\frac{\mathrm{U}_{95 \%} \mathrm{~F}}{\mathrm{k}_{\mathrm{F}}} \cdot \frac{\mathrm{b}}{(d-s)}\right|^{2}$ \\
\hline Panjang contoh uji & $\mathrm{gf}$ & normal & $\frac{\mathrm{U}_{95 \% \mathrm{~d}}^{\mathrm{r}}}{\mathrm{k}_{\mathrm{d}}}$ & $\frac{43 \mathrm{~F}}{(d-s)^{2}}$ & $\frac{\mathrm{U}_{95 \% \mathrm{~d}}}{\mathrm{k}_{\mathrm{d}}} \cdot \frac{43 \mathrm{~F}}{(d-s)^{2}}$ & $\left|-\frac{\mathrm{U}_{95 \% \mathrm{~d}}}{\mathrm{k}_{\mathrm{d}}} \cdot \frac{43 \mathrm{~F}}{(d-s)^{2}}\right|^{2}$ \\
\hline Panjang sobekan yang diteruskan & gf & rectangular & 0,73323 & $-\frac{43 \mathrm{~F}}{(d-s)^{2}}$ & $-\frac{31,52889 \mathrm{~F}}{(d-s)^{2}}$ & $\left|-\frac{31,52889 \mathrm{~F}}{(d-s)^{2}}\right|^{2}$ \\
\hline Panjang sobekan awal & gf & normal & $\frac{\mathrm{U}_{95 \% \mathrm{~s}}}{\mathrm{k}_{\mathrm{s}}}$ & $-\frac{43 \mathrm{~F}}{(d-s)^{2}}$ & $-\frac{\mathrm{U}_{95 \% \mathrm{~s}}}{\mathrm{k}_{\mathrm{s}}} \cdot \frac{43 \mathrm{~F}}{(d-s)^{2}}$ & $\left|-\frac{\mathrm{U}_{95 \% \mathrm{~s}}}{\mathrm{k}_{\mathrm{s}}} \cdot \frac{43 \mathrm{~F}}{(d-s)^{2}}\right|^{2}$ \\
\hline Konstanta & $\mathrm{gf}$ & rectangular & 0,86603 & $\frac{F}{(d-s)}$ & $\frac{0,86603 F}{(d-s)}$ & $\left|\frac{0,86603 F}{(d-s)}\right|^{2}$ \\
\hline Ketidakpastian gabungan & gf & & & $\mathrm{u}_{\mathrm{c}}$ & & $\mid \sum_{i=1}^{\underline{n}}\left(u_{i} \cdot c_{i}\right)^{2}$ \\
\hline Ketidakpastian bentangan & gf & & & $\mathrm{U}_{95 \%}$ & & $2 \cdot \mid \overline{\sum_{\mathrm{i}=1}^{\frac{6}{n_{i}}}\left(\mathrm{u}_{\mathrm{i}} \cdot \mathrm{c}_{\mathrm{i}}\right)^{2}}$ \\
\hline
\end{tabular}
pendulum (Elmendorf) secara ringkas dapat dilihat pada Tabel 1 .

Tabel 1. Estimasi ketidakpastian uji kekuatan sobek kain metoda pendulum (Elmendorf) 


\section{Kesesuaian dengan Spesifikasi}

Laporan pengujian, bila diperlukan untuk interpretasi hasil pengujian, harus mencakup, bila relevan, pernyataan atas kesesuaian/ketidaksesuaian dengan persyaratan dan/atau spesifikasi dan bila pernyataan kesesuaian dibuat, ketidakpastian pengukuran harus diperhitungkan. ${ }^{8}$ Bila ketidakpastian suatu pengujian diperlukan untuk menilai kesesuaian dengan spesifikasi, dan mempengaruhi kesesuaian terhadap batas spesifikasi maka penilaian kesesuaian harus memperhitungkan ketidakpastian bentangan yang dilaporkan dengan faktor cakupan dan tingkat kepercayaan tertentu. Beberapa keadaan yang mungkin dalam hasil uji dan ketidakpastian pengukuran, terkait kesesuaian dengan spesifikasi, seperti terlihat pada Gambar 15.

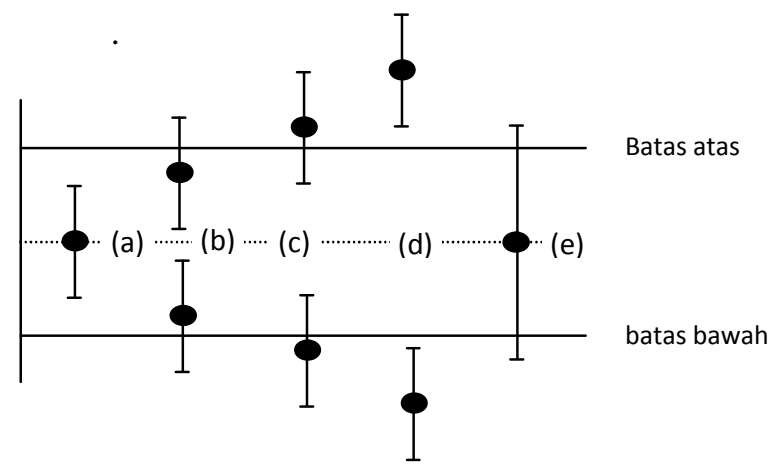

Gambar 14. Hasil uji dan ketidakpastian pengukurannya dalam kesesuaian dengan spesifikasi

Gambar 14 memperlihatkan bahwa hanya (a) yang memenuhi persyaratan, sedangkan yang lainnya (b, c, d, dan e) tidak memenuhi persyaratan. (a) menggambarkan hasil pengujian dan rentang ketidakpastiannya berada di dalam batas toleransi spesifikasi/persayaratan; (b) dan (e) rata-rata hasil pengujian masih dalam batas toleransi, tetapi rentang ketidakpastian pengukurannya keluar dari toleransi; (c) rata-rata hasil pengujian di luar batas toleransi, tetapi sebagian rentang ketidakpastiannya ada dalam batas toleransi; sedangkan (d) rata-rata hasil pengujian dan rentang ketidakpastiannya berada di luar batas toleransi.

\section{Aplikasi Model Pengukuran \\ a. Aplikasi Perhitungan Estimasi Ketidakpastian Pengukuran}

Hasil uji kekuatan sobek kain metoda pendulum (Elmendorf) dari tiga contoh kain, dengan gramasi $141,1 \mathrm{~g} / \mathrm{m}^{2}, 151,0 \mathrm{~g} / \mathrm{m}^{2}$, dan $167,6 \mathrm{~g} / \mathrm{m}^{2}$ dengan peralatan yang digunakan berikut:

1. Pola contoh uji

Panjang pola contoh uji dari dasar celah $(\mathrm{d})=$ $63,00 \mathrm{~mm}$ dengan ketidakpastian pengukuran $\mathrm{U}_{95 \%}=0,30$.

2. Alat uji sobek Elmendorf

- Panjang sobekan awal $(\mathrm{s})=22,40 \mathrm{~mm}$ dengan ketidakpastian pengukuranU $\mathrm{U}_{95 \%}=0,32$.

- Kesalahan relatif penunjukkan gaya Elmendorf $=0,00 \%$ dengan ketidakpastian pengukuran $\mathrm{U}_{95 \%}=0,41 \%$.

Hasil uji kekuatan sobek kain dan ketidakpastian pengukuran yang diperoleh dapat dilihat pada Tabel 2. Sedangkan perhitungan ketidakpastian untuk masing-masing jenis kain secara lengkap dapat dilihat pada Tabel 3, Tabel 4 dan Tabel 5.

Pada Tabel 2 terlihat bahwa gaya sobek (FS) yang dihasilkan berbeda dengan gaya yang ditunjukkan oleh alat uji Elmendorf (F). Hasil uji Elmendorf tidak memperhitungkan panjang contoh uji (d) yang dibuat dan panjang sobekan awal (s). Apabila selisih panjang contoh uji (d) dengan panjang sobekan awal (s) tidak sama dengan konstanta $\{(\mathrm{d}-\mathrm{s}) \neq \mathrm{b}(43 \mathrm{~mm})\}$, maka gaya sobek yang ditunjukkan oleh alat uji Elmendorf harus dikoreksi yaitu dikonversikan menjadi $43 \mathrm{~mm}$. Jika selisih panjang contoh uji (d) dengan panjang sobekan awal (s) sama dengan konstanta $\{(\mathrm{d}-\mathrm{s})=\mathrm{b}$ $(43 \mathrm{~mm})\}$, maka gaya sobek (FS) sama dengan gaya yang ditunjukkan oleh alat uji sobek kain Elmendorf (F). Dengan demikian, jika $(\mathrm{d}-\mathrm{s})<\mathrm{b}$, maka kekuatan sobek yang seharusnya adalah lebih besar dari penunjukkan alat uji sobek kain Elmendorf, begitu juga sebaliknya, jika $(d-s)>b$, maka kekuatan sobek yang seharusnya adalah lebih kecil dari penunjukkan alat uji Elmendorf.

Tabel 2. Hasil uji kekuatan sobek kain

\begin{tabular}{|c|c|c|c|c|c|c|c|c|c|}
\hline \multirow{2}{*}{$\begin{array}{c}\text { Gramasi } \\
\left(\mathrm{g} / \mathrm{m}^{2}\right)\end{array}$} & \multicolumn{7}{|c|}{ Hasil Elmendorf (kgf) } & \multirow{2}{*}{$\begin{array}{c}\text { Gaya Sobek, FS } \\
\text { (kgf) }\end{array}$} & \multirow{2}{*}{$\begin{array}{l}\mathbf{U}_{95 \%} \\
\text { (kgf) }\end{array}$} \\
\hline & 1 & 2 & 3 & 4 & 5 & $\bar{x}$ & sd & & \\
\hline 141,1 (Kain 1) & 2,22 & 2,15 & 2,19 & 2,23 & 2,11 & 2,18 & 0,05000 & 2,31 & 0,14 \\
\hline $151,0($ Kain 2$)$ & 3,06 & 3,29 & 3,12 & 3,12 & 3,29 & 3,18 & 0,10691 & 3,36 & 0,24 \\
\hline 167,6 (Kain 3) & 3,82 & 3,82 & 4,28 & 4,01 & 3,95 & 3,98 & 0,18902 & 4,21 & 0,29 \\
\hline
\end{tabular}


Pemodelan dan Estimasi Ketidakpastian Pengukuran Uji Kekuatan Sobek Kain Metoda Pendulum (Elmendorf) (Saeful Islam, M. Danny Sukardan)

Tabel 3. Contohkain 1estimasi ketidakpastian uji kekuatan sobek kain metoda pendulum (Elmendorf)

\begin{tabular}{|l|c|c|c|c|c|c|}
\hline \multicolumn{1}{|c|}{ Komponen Ketidakpastian } & Satuan & Distribusi & $\boldsymbol{u}_{\boldsymbol{i}}$ & $\boldsymbol{c}_{\boldsymbol{i}}$ & $\boldsymbol{u}_{\boldsymbol{i}} \cdot \boldsymbol{c}_{\boldsymbol{i}}$ & $\left(\boldsymbol{u}_{\boldsymbol{i}} \cdot \boldsymbol{c}_{\boldsymbol{i}}\right)^{\mathbf{2}}$ \\
\hline Repeatability hasil pengujian & gf & & 20 & 1,059 & 21,182 & 488,688 \\
\hline Penunjukkan gaya pada alat uji sobek & gf & normal & 4,469 & 1,059 & 4,733 & 22,403 \\
\hline Panjang contoh uji & gf & normal & 0,15 & 56,869 & 8,530 & 72,766 \\
\hline Panjang sobekan yang diteruskan & gf & rectangular & 0,73323 & $-56,869$ & $-41,698$ & 1738,706 \\
\hline Panjang sobekan awal & gf & normal & 0,16 & $-56,869$ & $-9,099$ & 82,791 \\
\hline Konstanta & gf & rectangular & 0,866 & 53,695 & 46,501 & 2162,354 \\
\hline Ketidakpastian gabungan & gf & & \multicolumn{2}{|c|}{$\mathrm{u}_{\mathrm{c}}$} & $\mathbf{6 7 , 2 8 8}$ \\
\hline Ketidakpastian bentangan & gf & \multicolumn{2}{|c|}{$\mathrm{U}_{95 \%}, \mathrm{k}=2$} \\
\hline
\end{tabular}

Tabel 4. Contohkain 2estimasi ketidakpastian uji kekuatan sobek kain metoda pendulum (Elmendorf)

\begin{tabular}{|c|c|c|c|c|c|c|}
\hline Komponen Ketidakpastian & Satuan & Distribusi & $u_{i}$ & $c_{i}$ & $u_{i} \cdot c_{i}$ & $\left(u_{i} \cdot c_{i}\right)^{2}$ \\
\hline Repeatability hasil pengujian & gf & & 42,764 & 1,059 & 45,292 & 2051,403 \\
\hline Penunjukkan gaya pada alat uji sobek & gf & normal & 6,5108 & 1,059 & 6,896 & 47,550 \\
\hline Panjang contoh uji & gf & normal & 0,15 & 82,851 & 12,428 & 154,446 \\
\hline Panjang sobekan yang diteruskan & gf & rectangular & 0,73323 & $-82,851$ & $-60,749$ & 3690,407 \\
\hline Panjang sobekan awal & gf & normal & 0,16 & $-82,851$ & $-13,256$ & 175,725 \\
\hline Konstanta & gf & rectangular & 0,866 & 78,227 & 67,747 & 4589,600 \\
\hline Ketidakpastian bentangan (gf) & gf & \multicolumn{4}{|c|}{$\mathrm{U}_{95 \%}, \mathrm{k}=2$} & 206,970 \\
\hline
\end{tabular}

Tabel 5. Contohkain 3estimasi ketidakpastian uji kekuatan sobek kain metoda pendulum(Elmendorf)

\begin{tabular}{|l|c|c|c|c|c|c|}
\hline \multicolumn{1}{|c|}{ Komponen Ketidakpastian } & Satuan & Distribusi & $\boldsymbol{u}_{\boldsymbol{i}}$ & $\boldsymbol{c}_{\boldsymbol{i}}$ & $\boldsymbol{u}_{\boldsymbol{i}} \cdot \boldsymbol{c}_{\boldsymbol{i}}$ & $\left.\boldsymbol{u}_{\boldsymbol{i}} \cdot \boldsymbol{c}_{\boldsymbol{i}}\right)^{\mathbf{2}}$ \\
\hline Repeatability hasil pengujian & gf & & 75,610 & 1,059 & 80,079 & 6412,655 \\
\hline Penunjukkan gaya pada alat uji sobek & gf & normal & 8,151 & 1,059 & 8,633 & 74,522 \\
\hline Panjang contoh uji & gf & normal & 0,15 & 103,72 & 15,558 & 242,052 \\
\hline Panjang sobekan yang diteruskan & gf & rectangular & 0,73323 & $-103,72$ & $-76,051$ & 5783,703 \\
\hline Panjang sobekan awal & gf & normal & 0,16 & $-103,72$ & $-16,595$ & 275,401 \\
\hline Konstanta & gf & rectangular & 0,866 & 97,931 & 84,811 & 7192,942 \\
\hline Ketidakpastian gabungan (gf) & gf & & \multicolumn{5}{|c|}{$\mathrm{u}_{\mathrm{c}}$} & $\mathbf{1 4 1 , 3 5 5}$ \\
\hline Ketidakpastian bentangan (gf) & gf & \multicolumn{2}{|c|}{$\mathbf{2 8 2 , 7 1 0}$} \\
\hline
\end{tabular}

\section{b. Kontribusi Komponen-komponen \\ Ketidakpastian Pengukuran}

Terlihat pada Tabel 2, Tabel 3, dan Tabel 4, bahwa ketidakpastian repeatability hasil pengujian, ketidakpastian panjang sobekan yang diteruskan dan ketidakpastian konstanta memberikan kontribusi yang besar dibanding komponen ketidakpastian lainnya. Besarnya kontribusi masing-masing komponen ketidakpastian pengukuran dari masing-masing contoh kain dapat dilihat pada Tabel 5.

Ketidakpastian konstanta memberikan konstribusi terhadap ketidakpastian total yang terbesar, yaitu untuk contoh kain 1 (35,30\%), contoh kain $2(32,83 \%)$ dan contoh kain 3 $(30,10 \%)$. Ketidakpastian konstanta ini disebabkan oleh ketentuan ukuran pada SNI ISO 13937-1 yang memberikan interpretasi yang beragam tentang ukuran panjang kain yang akan disobek (diteruskan sobekannya), yaitu $43 \pm 0,5,43 \pm 1,5$ dan $43 \pm$ 3,0.Agar mencakup ketiga kemungkinan tersebut maka diambil ketidakpastian terbesar yaitu $\pm 3,0$ atau $6,98 \%$ dari seharusnya. Besarnya agregat ketidakpastian konstanta, dapat perkecil dengan menetapkan panjang ukuran kain dengan toleransi yang kecil sehingga tidak menimbulkan adanya interpretasi yang beragam.

Adapun ketidakpastian panjang sobekan yang diteruskan untuk contoh kain 1 (31,65\%), contoh kain 2 (29,44\%), dan contoh kain 3 $(27,00 \%)$. Ketidakpastian panjang sobekan ini terhadap terhadap ketidakpastian total, dari ketiga kain contoh uji termasuk kategori kedua terbesar. Hal ini disebabkan oleh selisih panjang sobekan yang diteruskan antara kemungkinan terpendek dengan kemungkinan terpanjang adalah 2,54 mm atau menyimpang $5,91 \%$ dari seharusnya. Ketidakpastian panjang sobekan yang diteruskan ini dapat diperkecil dengan membuat pola contoh uji yang diluruskan dengan benang penyusunnya, juga dapat dilakukan dengan mengecilkan celah sobekan (<15 mm). 
Tabel 5. Agregat komponen ketidakpastian pengukuran uji kekuatan sobek kain metoda pendulum(Elmendorf)

\begin{tabular}{|c|c|c|c|c|c|c|}
\hline \multirow{2}{*}{ Komponen Ketidakpastian } & \multicolumn{2}{|c|}{ Contoh Kain 1} & \multicolumn{2}{|c|}{ Contoh Kain 2} & \multicolumn{2}{|c|}{ Contoh Kain 3} \\
\hline & $\left|u_{i} \cdot c_{i}\right|(\mathrm{gf})$ & Agregat (\%) & $\left|u_{i} \cdot c_{i}\right|$ (gf) & Agregat (\%) & $\left|\boldsymbol{u}_{i} \cdot \boldsymbol{c}_{i}\right|(\mathrm{gf})$ & Agregat (\%) \\
\hline Repeatability hasil pengujian & 21,18 & 16,08 & 45,29 & 21,95 & 80,08 & 28,43 \\
\hline Penunjukkan gaya pada alat uji sobek & 4,73 & 3,59 & 6,90 & 3,34 & 8,63 & 3,06 \\
\hline Panjang contoh uji & 8,53 & 6,47 & 12,43 & 6,02 & 15,56 & 5,52 \\
\hline Panjang sobekan yang diteruskan & 41,70 & 31,65 & 60,75 & 29,44 & 76,05 & 27,00 \\
\hline Panjang sobekan awal & 9,10 & 6,91 & 13,26 & 6,42 & 16,60 & 5,89 \\
\hline Konstanta & 46,50 & 35,30 & 67,75 & 32,83 & 84,81 & 30,10 \\
\hline Jumlah & 131,74 & 100,00 & 206,38 & 100,00 & 281,73 & 100,00 \\
\hline
\end{tabular}

Sedangkan kontribusi ketidakpastian repeatability hasil pengujian menempati urutan ketiga terbesar, untuk contoh kain 1 (16,08\%), contoh kain $2(21,95 \%)$ dan contoh kain 3 $(28,43 \%)$. Hal ini menunjukkan variasi penyimpangan dari rata-rata kekuatan sobek kain cukup tinggi. Karena alat yang digunakan mempunyai ketidakpastian pengukuran yang relatif kecil seperti pola contoh uji $\left(\mathrm{U}_{95 \%}=0,30 \mathrm{~mm}\right)$, panjang sobekan awal $\left(\mathrm{U}_{95 \%}=0,32 \mathrm{~mm}\right)$ dan penunjukkan gaya Elmendorf $\left(\mathrm{U}_{95 \%}=0,41 \%\right)$, maka penyebab besarnya variasi adalah kekuatan sobek kain tersebut yang mempunyai variasi cukup tinggi. Hal ini dapat diperbaiki dengan menambah sampel uji, sehingga semakin banyak sampel uji maka rata-rata yang diperoleh akan mendekati ratarata populasi.

\section{KESIMPULAN}

Ketidakpastian merupakan indikator kunci untuk menilai kualitas dari suatu hasil pengukuran atau pengujian, antara lain untuk mengevalusi reliabilitas hasil, untuk membuat perbandingan yang valid antara dua hasil atau lebih, dan untuk menilai apakah hasil pengukuran atau pengujian tersebut sesuai dengan tujuan penggunaannya.

Dari penelitian ini dihasilkan formulasi yang dapat dijadikan acuan untuk menghitung bearnya gaya sobek dan menghitung besarnya ketidakpastian pengukuran dalam uji sobek kain metoda pendulum (Elmendorf), adalah sebagai berikut :

$$
\mathrm{FS}=\mathrm{F} \cdot \frac{\mathrm{b}}{(\mathrm{d}-\mathrm{s})}
$$

Dengan:

FS = gaya sobek, gf atau N

$\mathrm{F}=$ hasil uji alat (Elmendorf), gf atau $\mathrm{N}$

$\mathrm{b}=$ konstanta panjang sobekan yang

diteruskan, $43 \mathrm{~mm}$ $\mathrm{d}=$ panjang contoh uji (pola contoh

uji), $\mathrm{mm}$

$\mathrm{s}$ = panjang sobekan awal, $\mathrm{mm}$

Komponen ketidakpastian pengukuran uji kekuatan sobek kain metoda pendulun (Elmendorf) adalah repeatability hasil uji, penunjukan gaya pada alat uji sobek (Elmendorf), panjang contoh uji, panjang sobekan yang diteruskan, panjang sobekan awal dan konstanta ketetapan ukuran pada metode uji (SNI ISO 13937-1:2010).

Dari keenam komponen tersebut yang memberikan kontribusi yang cukup besar pada keidakpastian pengukuran yang dihasilkan adalah ketidakpastian repetability hasil pengujian, ketidakpastian panjang sobekan yang diteruskan dan ketidakpastian konstanta.

Penelitian ini dapat dijadikan acuan oleh laboratorium uji dalam memenuhi persyaratan SNI ISO/IEC 17025 dalam mengestimasi ketidakpastian pengukuran uji sobek kain metoda pendulum (Elmendorf).

\section{PUSTAKA}

${ }^{1} K A N-G-01:$ KAN guide on the evaluation and expression of uncertainty in measurement, no. 3. Komite Akreditasi Nasional Indonesia, 2011.

2 B. N. Taylor and C. E. Kuyatt, NIST Technical Note 12971994 Edition, Guidelines for Evaluating and Expressing the Uncertainty of NIST Measurement Results. Gaithersburg: National Institute of Standards and Technology, 1994.

${ }^{3}$ ISO/IEC Guide 98-3. Uncertainty of measurement Part 3: Guide to the expression of uncertainty in measurement (GUM:1995). Switzerland: International Organization for Standardization/International Electrotechnical Commission, 2008.

${ }^{4}$ K. Birch, Measurement Good Practice Guide No. 36: Estimating Uncertainties in Testing. Teddington: British Measurement and Testeing Association, 2001. 
5 A. M. Saviano, R. O. G. Madruga, and F. R. Lourenco, "Measurement uncertainty of aUPLC stability indicating method for determination of linezolid in dosage forms," Measurement, vol. 59, pp. 1-8, 2015.

${ }^{6}$ M. A. L. Traple, A. M. Saviano, F. L. Francisco, and F. R. Lourenco, "Measurement uncertainty in pharmaceutical analysis and its application," Journal of Pharmaceutical Analysis, vol. 4, no. 1, pp. 1-5, 2014.

7 A. M. Saviano and F. R. Lourenco, "Uncertainty evaluation for determining linezolid in injectable solution by UV spectrophotometry," Measurement, vol. 46, no. 10, pp. 3924-3928, 2013.

${ }^{8}$ T. Y. Wu and Y. L. Lu, "Error analysis and uncertainty estimation for a millimeter-wave phase-shift measurement system at $325 \mathrm{GHz}$," Measurement, vol. 59, pp. 198-204, 2015.

9 A. Cataliotti, V. Cosentino, D. Di Cara, A. Lipari, and S. Nuccio, "A DAQ-based sampling wattmeter for IEEE Std. 1459-2010 powers measurements. Uncertainty evaluation in nonsinusoidal conditions," Measurement, vol. 61, pp. 27-38, 2015.
10
SNI ISO/IEC 17025: Persyaratan umum kompetensi laboratorium pengujian dan laboratorium kalibrasi. Jakarta: Badan Standardisasi Nasional, 2008.

11 B. Witkowska and I. Frydrych, "A Comparative Analysis of Tear Strength Methods," FIBER \& TEXTILE in Easter Europe, vol. 12, no. 2, pp. 42-47, 2004

12 SNI 0051: Kain tenun untuk kemeja. Badan Standardisasi Nasional, 2008.

13 SNI 08-0108: Kain georgette poliester $100 \%$. Badan Standardisasi Nasional Indonesia, 2006.

14 SNI 08-0056-2006: Kain tenun untuk setelan (suiting). Badan Standisasi Nasional Indonesia, 2006.

15 SNI ISO/IEC 13947: Tekstil - Kekuatan Sobek kain - Bagian 1: Cara uji kekuatan sobek menggunakan metoda pendulum (Elmendorf) Textiles - Tear properties of fabric - Part 1 : Determination of tear force using ballistic pendulum method (Elmendorf), vol. 1. Badan Standardisasi Nasional Indonesia, 2010. 